\title{
York in the Sixteenth and Seventeenth Centuries
}

$D^{\text {URING the fourteenth century the trade of York had developed }}$ the Lancastrian rule, and became a centre of disaffection, for the imposing personality of archbishop Scrope gained him a large following in opposition to Henry IV. The paramount influence of the earl of Warwick, whose principal Yorkshire seat was at Middleham Castle, induced the people of York to espouse the Yorkist cause in the wars of the Roses, and Edward IV on his march to Scotland was entertained royally within its walls. Renowned as York was for its liberality on these occasions, its hospitality seems to have been taxed too severely, for Sir John Paston, when arranging for a royal visit to Norwich later, warns the people ' to provide them wine enough lest the town be drunken dry as York was when the king was there.' Richard, duke of Gloucester, shared his brother's popularity; he was a member of the York gild of Corpus Christi, and more than once obtained from the king special privileges for the city. After be became king he visited York, whero handsome presents were lavished upon him, the creed play was enacted for his benefit, and feasts were held in his honour. Richard seems to have recognised the importance of the occasion, for he despatched a special messenger to London for certain robes of state, 'one dowblet of purpill satyn, one dowblet of tawney satyn, two short gownes of cremisyn cloth of gold, oone gowne of grene velvet lyned with tawney sattyn,' and numerous other articles of finery. Richard's death at Bosworth was bitterly lamented in York. This possibly led Henry VII to regard the city with suspicion. Whether this royal disfavour had a sinister influence on its welfare, it is difficult to determine, but the fact remains that the accession of the Tudors is coincident with the beginning of the decay of its industrial prosperity. It had passed scatheless through the trying period of the wars of the Roses, in fact it was at the height of its prosperity under Edward IV, the burghers had calmly bought and sold and added to their wealth while the bloody battle of Towton was being fought a few miles from their walls; but many causes, more far-reaching than the passing disfavour of a 
king, were undermining its position as the centre of northern industry. The tide of commerce was setting in the direction of the freer towns, where trade could be pursued unhampered by gild or other restrictions; the selfish shortsighted policy of the burghers, with their petty jealousy of the 'interlopers,' was driving the woollen trade to Wakefield and Huddersfield. York had lost another branch of industry ; it was no longer a place where foreign goods were disembarked; nature itself had played her false, the tide did not rise so high as formerly, certainly not high enough to float the heavier and larger vessels, which the longer journeys and more bulky freights rendered necessary. Hull had monopolised the northern carrying trade. It was indeed a dics funesta for York when Edward I, seizing with his quick statesman's eye the possibilities of the position, had determined to do his utmost to expand the trade of Hull. He had been struck with the resemblance between the flat marshy land which surrounded it and his own Aquitanian dominions, and determined Hull should be for the North Sea and northern Europe what Bordeaux was for the Atlantic and southern Europe. Two centuries elapsed before his dream was completely fulfilled, but the seaport grew steadily. York, with its stately minster, its gorgeous monastic buildings, its well-organised municipal life, its unimpoachable traditions, at first looked with scorn on its parvenu neighbour, but its scorn was soon changed into jealousy, its jealousy into rivalry, its rivalry into sullen acquiescence in its rival's success. Hull owed its origin to royal foresight, its maintenance to royal favour. The constant European wars of the sixteenth century made the kings view the shipping interest with peculiar favour, for an increase in the number of ships meant an increase in the security of the English shores. Hull made the most of her opportunities; she pursued a policy of self-interested generosity; her liberal contributions to the marine defences, her spirited efforts to save the royal exchequer, were rewarded by grants of trade privileges.

This new development was regarded by York with dismay; her rival's increase meant her decrease, and the municipal records are full of the acrimonious correspondence carried on between the two mayors. The parliamentary representatives were respectively urged to contest any advantage gained by the rival town. The see-saw story is wearisome in the extreme; still it shows the gallant effort York, representing the old well-established towns, made to retain the pre-eminence. But the woollen trade was even more jealously watched than the shipping. Here again York had a prescriptive right, for under Edward III it had been a staple town, and the buying and selling of wool for the greater part of the north of England had taken place in its markets. In the sixteenth century the trade languished; an industrial change was passing over the 
country. England no longer produced wool to export and to be imported again when manufactured into cloth, but manufactured her own wool; and cloth, not wool, becsme the staple export, the export of wool under Elizabeth being forbidden. This ought not, however, to have told against the prosperity of York, for she still enjoyed the monopoly of the manufacture of cloth for the whole county, and was specially exempted from the statute limiting the number of looms and apprentices of weavers. The real cause of the decay was her jealousy of aliens; in 1565 Norwich sought and obtained leave for some of the foreigners who hod come from Flanders to settle in their town, where the wesving industry was decaying, and the London weavers made an agreement with the foreigners, but York refused to countenance such irregularities, and was so far successful that in the middle of the sixteenth century there were only four Frenchmen in the whole of York.' The result of this shortsighted policy is clear from the following correspondence, which is interesting ss showing the causes to which the people of York themselves attributed the decey.

To our moste gracious souvereigne ladye the Queenes Majestie. In moste humble wyse showe unto yor moste excellent majestie yor obedient faithiull subjectts the mayor aldermen \& sheriffes of yor graces citie of Yorke That whereas in olde tymes past the sside cittye hath moche prospered in clothe makyng \& thereby the occupation of weavers of the same citie being then both many and of good repute obtained by charter of yor highnesses moste noble progenitors to be incorporated holding for 8 fee ferme a certayne yerely some in yor high corte of exchequer which yerely fee ferme was paid accordingly so long as webbyng in the said citie was used. But lyke as moste gracyous sovereign in processe of tyme the said occupyng decreased and at last utterly decayed in the said citie even so the weavers of the same bothe wantying their accustomed occupying and also being overchardged with the said yerely payment have fled the moste parte out of the citie inhabiting in the country to the same nigh ajoining safe onely a fewe very poore men nowe remaining whoe no dowbte if they be compelled to paye still the said yerely fee ferme shall also in shorte tyme be fayne clerely to forsake $y 0^{2}$ graces said citie to the grete discommoditee of the same. ${ }^{2}$

This gloomy epistle brought an immediate answer, in reply to which the mayor gives more specific information on the state of trade.

Accordyng to yor lordshippes will \& pleasure the mayour of this citie of Yorke have caused diligent enquiery \& serche to be made what number of weavers \& loomes for woollen clothe are within the same and thereupon doo finde and perceyve that there are in the said citie not above tenne weavers who can worke bothe linen and woollen and that their lyvyng is of lynen.

Also there is presently remayning in the seid city four woollen loomes

- Pork Corporation Miuntes, 1 Eljz. book xxii. 1. 107.

2 Ibid. 3 Eliz. book xxiii. 1. 14. 
onely, which for the mooste part doe stande unoccupied for the lak of worke. Moreover one Richard Marshall of the said citie marchant did latly sett up drapyng in this citie and had oone woollen loome thereof his owne but because be founde no gaynes at it he hath left off and the cause of the decay of the said weavers \& loomes is the lakke of cloth makyng in the said citie as was in old tymes accustomed which is nowe encreased \& used in the townes of Halyfax Leedes \& Wakefield for that not onely the comoditie of water mylles is there neigh hande but also the pooro folke as spynners, carders \& other necessary work fowlkes for the said webbyng, may there besides there hand labor have rye fyre and other relief good cheap which is in this citie very deare \& wantyng. ${ }^{3}$

No reference is here made to the standing grievance of the York weavers, the presence of the foreigner, but in 1606 they petitioned the mayor to allow them to add a very stringent clause to their ordinances by which any one employing foreign labour, i.e. employing any one who was not a freeman, was to be fined forty shillings for each offence.

There was a general tendency to blame the municipal authorities for this state of affairs; some extreme radicals even went to the extent of saying if they feasted less and thought more of the city's welfare trade would improve. This was, however, unjust, for their refursal to countenance foreigners was regarded as sound policy, and in other matters their only fault seems to have been over-anxiety. It was owing to civic enterprise that towards the end of the reign of Henry VIII the coverlette act, which gave the monopoly of that branch of trade, was obtained. The city council constantly interfered to keep up a high standard of workmanship ; they issued regulations to ensure the cloth being well woven and of right measure. In Elizabeth's reign they went a step further; the whole trade was rigorously supervised, and the civic authorities seem to have started a corporation spinning and weaving business. The municipal records are full of allusion to this enterprise.

Four pares of sheeres shalbe bought and other necessaries in redyness for dressers of the city cloth by sight of the workmen and also that spynners shalbe spedy as well of the country as citie to spynne so that websters may have sufficient work. ${ }^{4}$

The following month the high price at which the corporation tried to dispose of the cloth is complained of; but Mr. Andrew Trewe, who was one of 'the prasers thereof,' proved his faith in the justice of his valuation by taking the cloth at his own price. Although the expedient of providing for the unemployed by setting up looms was often resorted to, strenuous precautions were taken against the work being scamped. The looms were set up at St. Antony's Hall on Peaseholm green, which seems to have been a

- York Corporation Minutes, 3 Eliz. book xxiii. \&. 20.

- Ibid. 12 Eliz. book zxiv. 1. 192. 
forerunner of the modern workhouse, or St. George's house, outside Micklegate Bar.

That the poore folk of this citie suche as are founde able to doo some work shalbe brought by the constable of every parishe where they dwell into Saynt George's House where the citie wool lieth then \& there to be proved by the Aldermen wardens and XXIIII with the advyse of Roger Lyhe clothier what they can doo and suche of them as can doo oughte or are mete to learne to have wool delivered theym and the said Roger to do his diligens to instruct suche of the saide poore as he shall perceyre not perfect, but suche as he shall see hable and not willyng to labor or learne to labor to informe the saide lorde mayor.s

In spite of all these efforts the cloth trade of York gradually dwindled. But the enterprising York traders had no intention of sitting down calmly under defeat. As they failed to bring the guilt home to any particular class, the idea seems suddenly to have struck them that the Ouse was the principal delinquent. Early in the century they had been at immense expense in restoring Ouse bridge. Even then they had so far overcome their prejudice against strangers as to have an architect from London; now, however, they went a step further, and the hated alien was commissioned to widen and deepen the river. The transaction roused the greatest interest, and the discussions in the council chamber were more numerously attended than usual. It is interesting in this age of tender by telegraph to compare the more leisurely ways of the city fathers three hundred years ago.

3. J8n: 1616.

And whereas upon a petition preferred by diverse merchants of this citie it was ordered that John Hart being by Gods permission for to go into Holland shoulde enquire of a skillfull man who had knowledge in cuttyng of rivers and to knowe what he would take for comyng over to vewe the river and giving his judgement thereof and at his returne to certify what he shall have done therein and thereupon the court to consider whether be should be sent for or no and now the saide John Hart hath certified being returned that he hath broughte over with him thre duchmen one that is perfect and the other two in cutting of rivers and he was by men of judgment in Holland so far to doe and showed that he had agreed to give them for their paynes $44 Z$ over \& besydes all their chardges in bringing them into England and in their returnyng into their owne countries alledging that he was inforced to bring them over this winter for that after the spring of the yere they would not have been brought into England but at an extraordinary chardge by reason of ther great employment in their owne countries which this courte takyng into consideraton did much dislike that he had done contrarye bis direction in bringing them over before he had first certified my Lord Mayor and had ther directions to have brought them over. Notwithstanding for that the said Duchmen were come over this courte did thinke it very mete that they should viewe \& survey the same river and that 
the same John Harte and some merchants and mariners should go with them for the viewing thereof.

And now the thre duchmen who were brought forth of Holland have taken a viewe of the river and delivered a plotte thereof how and in what manner the same may be helped by somecutts and makyng two slucs . . . it is thought mete that Jobn Hamonson the engineer shall remayne here until the king coming in this cittye and to have 40s. a month and his diett paid for and the other too duchmen to have libertye to departe and that they shall have $44 \mathbb{2}$ which was covenanted by John Hart to be given unto them. ${ }^{6}$

The real difficulty was want of money. Possibly the preparation for the king's reception had exhausted their means; but two of the councillors came to the rescue of the distressed council chamber. The royal visit was made the excuse for one of those small dramatic displays in which, in spite of puritanic influence, the York people still delighted. But they determined to combine business and pleasure. By the startling apparition of a figure rising as if from the waves at the very moment when the king reached Ouse bridge, and reciting a poetic effusion, made for the occasion, they hoped to arouse James's interest in their disappointing river. The adroit mixture of flattery and business is an amusing feature of the poem.

What sudden joy is this. A great one sure

For now I do perceive I have a power

To break out of my melancoly bower

With able nerves ol what blest sun darts forth

Such comforth upon one and all the north

Oh nowe I do discerne him by his rays

'Tis he that makes our happynes and dayes

The firste exceed arithmetic the last the last

So glorious thet we do no winter taste

And I the genius of this aged flood

Who auntiente chronicles still great \& good

Though long impresoned by some envious groundes

That have encroached upon my natural boundes

And pent me so that thes sad stones do knowe

I scarce have means to ebb or power to flowe

Do nowe putt off my long oppressing feares

And bere drye up my self consuming tears

For well I know that thou the author art

Of peace \& libertye to earth's grieved hart

Nor do I nowe repente I syrens brede not

Such is this virtue that a charme I need not

To incyte thee to 8 worke of charity $\theta$

Whose everie acte is noughte but charite

And will I know enlarge my scanted scope

Whose hopes in one so good can lose no bope.7

- York Corporation Miuntes, 13 James I, book xxiii. t. 114.

- Ibid. 13 James I, book xxxrii. t. 119. 
The city was most anxious that a tax might be levied on the whole of Yorkshire for 'the amendyng of the river.' A bill to this effect was presented to parliament, but on its second reading formidable opponents rose, ' $\mathrm{Mr}$. Thomas Wentworth and diverse principall persons of Yorkshire,' who proposed that the money should be raised by an additional tax on every last or ton of goods coming up the river, and to this York had to submit.

No feature of sixteenth-century life is more difficult to grasp than the paramount importance of the gilds and companies. In York foreign trade was regulated by the merchant adventurers and the eastlanders, home industries by the various gilds. At every step the workman found himself confronted by these trade restrictions. Before a boy could be bound an apprentice he had to show he was a native of the city, and his seven years' apprenticeship did not end his obligations, since he had to take up his freedom of the city before he could begin business for himself. Doubtless in foreign trade some sort of combination was necessary, for the Hanse merchants had gained such a firm hold on the English shipping trade that they were most difficult to dislodge. But favoured by Edward VI and Elizabeth, the merchant adventurers had driven them from the field. The York adventurers were a flourishing body as early as 1370 ; they were sufficiently rich to found a hospital and chantry in Fossgate, where thirteen old people were maintained at the company's expense. They had received a charter from Henry VI, but Elizabeth granted them more extensive privileges; they had some features in common with the staplers, but were composed entirely of Englishmen. Their secretary describes them as consisting of a number of wealthy and well-experimented merchants, dwelling in diverse great cities, trading in cloth and kersie and all otiner as well English as foreign commodities. They were free from any interference from the company in London, except that their governor had to be free of the central gild, and they seem to have exercised a sort of supervision of all the trades, analogous to that exercised by the old gild merchant. A quaintly worded petition sent to the governor shows how he was appealed to by the unsuccessful tradesman.

In moste humble wyse compleyneth sherreth and besecheth your honourable Lordshipp and assistants your poore brethren the merchaunts being retayllers in the said cittye whereas heretofore the merchaunts resydant \& inhabitying in the citie of York have been in there art misterye or scyence grestlye traffiqued exerceysed and occupied as well for the sustentation of themselves, ther wyves and famylyes as for the good educasion of the youthe ther apprenteces so notwithstandyng that by reason of dyverse artyfycers hevyng manuall occupation daly exercysyng usyng \& occupyng the retayle of the said scyence or misterye your saide poore Brethren the merchaunts retayllers are not onely less traffiqued lesse 
occupyed and therebye utterlye impoveryshed there youthes not trayned in the said mysterye and therebye the saide mysterye and scyence much impaired unlesse youre honourable assistance and aid for the redress of the premisses be specylye showed as by your good advisers and counsell shalbe thought moste expedient \& requisite, whereunto you are not onely bounden by our charter but also by publicque and solemn othe whereby we are constrayned to relate and speak these wrongs which dayly are aggrevated upon us by the artificers of this cytye trustyng to some spedye reformation of the same for it is written in the Book of God whoso robbeth his neighbour of his lyvyng doeth as great synne as though be slew him to death if your honour and worshipps wold consyder the state of your poore Brethren we doubte not that you will confesse that we are robbed and spoyled of our lyvyng by the artificers of this cittye. ${ }^{8}$

What reply the governor made to this appeal we do not know.

The merchant adventurers seem to have been independent of the supervision which the mayors exercised over the other trade gilds of York. In some towns in the seventeenth century, the gilds as a rule derived their coercive power from parliament or the king, not as formerly from the municipal authorities. This is doubtless true of the more important companies, as merchant adventurers and merchant tailors, but in York gild life was continuous ; there was no distinctly marlsed period of depression under Edward VI and Mary, as there was in the history of some of the English gilds. For the greater part of the seventeenth century numbers of smaller gilds existed, which constantly appealed for the mayor's permission to alter their regulations, to add new clauses or to enforce their ordinances. As a rule the mayor was the final referee in any trade dispute, and the officials rarely refused to submit to him.

The merchant adventurers continued a powerful company until the middle of the eighteenth century. They still exist, though diminished in numbers, deprived of their privileges and shorn of their wealth. They made a last effort to maintain their power in 1832, when they brought un action agninst a druggist who had set up business in York not being a member of their company. They lost the case, and the law expenses amounting to $1000 l$. they were forced to part with some of thcir property to cover them. They still maintain the old pensioners, five men and five women, to whom they pay $9 s .4 d$. a month. Until a few years ago these old people lived in four large rooms under the hall in Fossgate, but the rooms were damp and unwholesome, and they are now boarded out with their friends or relations. A service is beld once a year in the quaint chapel under the meeting hall, on 20 Sept., the expenses being defrayed by a fund left in 1644 by Mr. Thomas Herbert for the purpose. After the sermon the brethren of the company hold a reception, and provide afternoon tea.

The adventurers had the monopoly of trading from the mouth

- Minute Book of the York Merchant Adveniurers. 
of the Somme as far as the Cattegat, but the trade of Norway, Sweden, and the Baltic was principally in the hands of the esstlands company. They were not so ancient a company as the adventurers, but seem to hove been the aristocrscy of commerce, many well-known Yorkshire names occurring among their list of apprentices, Pennyman, Belssyse, Cholmley, Bendlowes, Büdett, Lascelles, and Wyvills. They seem to have been on very friendly terms with the adventurers, on one occasion Sir Henry Thompson being both governor of the adventurers and deputy of the eastlanders. They suffered from a serious disadvantage, for they owed a sort of allegiance to the eastlanders in London, who elected their officers, and exercised a general supervision over their doings. This wes gelling to the pride of the York merchants, who were most anxious to shake off the yoke of the parent gild, but were by no means adverse to taking upon themselves the same responsibilities towards the northern eastlanders, settled at Leeds, Newcastle, and Hull. The York merchants refused to give in their accounts until the company. in London had given them an answer to their request to elect their own deputy and to have a court of assistants like the one in London. The company allowed some time to elapse before they replied, then wrote, more in sorrow than anger, a grandiloquent letter, never, however, touching on the real point of dispute.

We hope that time which changes all things has also changed the state of affairs at your resydence from what it was \& that that misunderstandyng (to give it the softest name we can) which you have hed of our proceedings, is by this time thoroughly removed for after all these heats you have had leisure to consider in cold blood whither these differences tend which have been raysed smong us and if the dregges of that distemper by standing atill soo unmoved have settled to the bottom may noe malitious hand shake or trouble it agane to disturb the peace of the fellowshippe nor would we be content barely to have these animosities skimmed over, but skilfully hesled and therefore we pass by \& forget them that not 80 much as $B$ skarr may be left to discover the sore by. ${ }^{9}$

The tailors were 8 very ancient gild. The more ambitious title merchant tailors, by which they were known in the sixteenth century, was first conferred by Henry VII, ' in consideration of their hoving immemorially exercised merchandize in all parts of the globe,' upon the London gild, but the tailors of York were similarly chartered the same year. They seem to have had a general supervision of the textile industries within the city. In 1656 they found their power of enforcing their ordinances decreasing, and appealed to the mayor to uphold their authority: the request was granted, and the searchers were empowered to enter into the house of any one refusing to pay the fine levied by the gild, and seize his goods. The arrangement does not seem to have worked

- Mirruto Book of the Eastland Merchants, \&. 66. 
satisfactorily; for some yesrs later we find the tailors obtaining a charter from the king, Charles II, which reasserted and consolidated their powers. They still carry on their meetings in the hall in Aldwark, over the door of which is their motto, 'Concordia parrae crescunt res.'

In spite of the efforts of the companies and gilds, the dreary story of the decey of trade drags on. Intense jeslousy of the coming of strangers and foreigners meets us on every page of the municipal records. Even the strolling player and musician is objected to. Some of the citizens wishing to have a theatre suggested that 'it might be a means to restroyne. the frequent comminge thereunto of other stage players ; ' the corporation agreed under certsin conditions which they promised to publish later. The citizens, taking this conditional promise absolutely; at once got together their players, erected a theatre, and set to work to amuse the people of York. This roused the indignation of the city fathers : possibly a more puritanic element had been introduced into the council; in any case the conditional consent was withdrawn. The fascinations of the stage had evidently exercised too much influence, for the promoters of the scheme were accused of drawing ! into their companyes strangers that did inbabit in the countrie and likewise some of manuell occupations in this cittie who do intend to give over ther occupations and fall to an idle course of life.' 10

But slowly the ides was gaining ground that the good of the city might occssionally require the admittance of the hated stranger within the gates. Exceptional talent, lack of workpeople of the same trade, influential connexions, sometimes broke down the barriers which prejudice had raised, and people were admitted to the freedom of the city without paying the customary fee; in return for this generosity they generally gave some specimen of their workmanship to the council.

William Kidson clockmaker, who is commended by diverse knights and others of good worth to be verie skillfull in that arte or scyence of makgng silver clocks now for that there is not within this citie that is skillfull or perfect in makyng or amending of them therefore this courte is well pleased to bestowe the freedome of this citie upon him without paying any money for the same. Whereupon the said Willism Kidson did voluntarelie offer to give to the corporation a clock to remeyne in the oourt."

Benedicki Horsley, \& 'pictorer and psinter,' was admitted aí \& reduced fee, on condition that he set up the ten commandments in the sheriffs' court. ${ }^{12}$ The old order was changing, but nowhere was the change more strenuously resisted than in York. There is

1o York Corporation Minules, 6 James I, boot zzsiii. t. 187.

"Itid. 8 Jasmes I, book zxsiii. L. 18.

12 Iovid. \& Janos d, book 88siil. P. 95. 
somothiag olmogt pathotic in the insbility of the old city to adspt itsel 8 to new eircureastances; its refussl to truckle to the new spirit of fres comperition is dignifed if unprectical. Nowhero was the heretical opiaion odvasaced in the honse of commons in 1621 thet gilds and corapesnies should bo swept sway like any other monopoly more detested shen in York. Blow sfiter blow hod been aimed ot its pro-eminence. The suppression of the monasteries had robbed if of ite rich monsstic esteblishments, the growth of puritsnism hod pat down the shows and psgernts which delighted the inbsbitrats and strrected visitors to the city, new industrial conditions

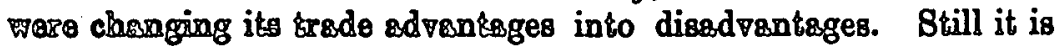
irajgorsible fo blswe those in whose hands the mansgement of afisirs wes pleced. On the whole the study of the racords lesves an inopression of strictly defined objects pursued with sterdy English Faresisence. Bhay of these objects seem to us sbsurd, but their intention was not indelensible. The laws agringt sliens dealt the dersthblow to the cloth trade in York; still the town wes not cooded, sad the stendard of living lowered, by swarms of poor \{0raignars. The strict gild regulations seem tyrennical, still before she of of compatition some check on dishonest trading was necassssy. A mon who had been sentenced

so be satto upon o scastolde in opan market with a paper on his forehead rrxiston in grets lottars Thais is for mixing white wer with rossall and turpantyno sogether \& puttyng the same to seyle for good wBX to the grats decsipte of the Queenes subjects, and to have two caltes of wess hong on him one bahynde and one before and so continue there untyll one of the cloke in the aferacon and then to be hedde to prison ${ }^{12}$ would not be likely to offend again. The unfortunste cobbler who W\&s imprisoned for keeping boots longer then thres deys when repoiring them poseibly inveighed against the low, but bis curtomers doubtloss rejoiced. ${ }^{10}$ Even in the midst of ninefeonth-century civilisetion we cannot help feoling a slight lingering regres for tho timo when cosmopolitenism was regarded as a vice, when the objection to dishonest trading was not looked upon a \& narrow prejudice incompatible with wide commercial views, or afosling as an empty ' fost when it's so lucretive to chesi.'

MAOD BELLERS.

10 Ibid. 14 Rliz. book zxiv. \&. 366.

14 Ibid. 6 James I, book z8xiil. 4. 116. 